\title{
IMPROVING TEENAGER'S CREATIVITY SKILL OF ART AND CULTURE AND CHARACTER BUILDING OF ISLAMIC JUNIOR HIGH SCHOOL STUDENTS
}

\author{
Tengku Silvana Sinar ${ }^{*}$, T. Thirhaya Zein ${ }^{1}$, Rudy Sofyan $^{1}$, T. Mira Rozanna ${ }^{2}$ \\ ${ }^{1}$ University of Sumatera Utara, Medan, Indonesia \\ ${ }^{2}$ Islamic Junior High School of Sinar Serdang Perbaungan, Medan, Indonesia \\ *Corresponding Author: tengkusilvana@usu.ac.id
}

\begin{abstract}
Creativity Skill of Art and Culture Program (PKKSB) aims to give a training in dancing, pantun reciting and Malay cultural drama to the Junior High School and Islamic Junior High School students of Sinar Serdang which located in Perbaungan, Serdang Bedagai Regency, North Sumatera. As its name, PKKSB has goals to make the students be able in appreciating traditional culture and local wisdom through Malay dance, pantun reciting and drama. By providing the training, the students now have experiences in expressing, creating, and appreciating the art and publicly performing Cultural Arts in an event held by the governing boards of Serdang Bedagai Regency. This Cultural Arts Performance is held with the aim of conserving and developing the culture for young generations or wider communities.
\end{abstract}

Keywords: Art Creativity; Culture; Local Wisdom; Character Building.

\section{INTRODUCTION}

Improving art and cultural creativity has a very wide dimension. In term of art and culture, it divides into dance, music, literature, theater, and many more. Through Department of Education and Culture, government has made many efforts by providing the widest opportunity for Indonesian children to get 12 years of compulsory education. Also, the schools are urged to create the best graduates especially in facing the current global competition by facilitating the right quality of education for students through improving the facilities and infrastructures, revamping education system and school administration, developing teaching materials, and providing training or additional lessons for the students. Government set the learning of each subject in order to form a smart intrapersonal, interpersonal, visual, spatial, musical, linguistic, mathematical logic, creativity intelligent, emotional intelligent, spiritual and moral intelligent.

To find their interests and talents in achieving the multi-intelligence through training of art and culture, students' appreciation toward traditional culture and local wisdom play important roles as it explores all sides of the expected intelligence. Thus, learning art and culture needs to be developed in order to lead the students become a superior individual.

The formation of a strong national character is a key to success in national development process. Constitutionally, the importance of character building in accordance with the national identity of Indonesia has been stated in the National Long-term Development Plan of 2005-2025, namely "the realization of a tough, competitive, noble, and holds the values of Pancasila, characterized by character and humans behavior and the Indonesian people who are diverse, faithful, and devoted to the Almighty God, virtuous, tolerant, cooperative, political-minded, dynamically developing, and science-oriented".

So, in order to instill good habits to the students as how Mulyasa (2012) has mentioned above, certainly character building in accordance with the background of socio-cultural owned by the students who have potential or based on local wisdom needs to be done in the context of strengthening the nationalism and cultural preservasion to grow and strengthen the national identity in the era of globalization. Consequently, character building which aimed at forming the national identity can be done based on the local wisdom owned by the local society or communities.

However, art and culture subject are still hard for students to learn. Based on a discussion with the partner, it can be seen that the scores of students' art and culture subject are still low. The lack of interest in learning art and culture caused by the students who still consider that local art and culture are not necessary and less fun whereas the foreign art and culture are more appreciated.

Junior High School (SMP) and Islamic Junior High School (MTs) of Sinar Serdang are located in the city of Perbaungan, Serdang Bedagai Regency, North Sumatra. These schools have 2 hours per week for art and culture 
subject where the learning of art and culture is limited to dancing. Yet, it has not fulfilled the curriculum that focuses on four main fields, namely fine arts, music, dance, and theater.

Islamic Junior High School (MTs) of Sinar Serdang was chosen as a partner in doing USU community service (PKM) as the school keep continuing its efforts to increase cultural art values and reach the goals of fair and equal education even for disadvantaged community group. As a new developed city, Perbaungan still needs a lot of attention from the provincial government. Since its separation from Deli Serdang Regency, in the past few years, Perbaungan people still continue improving the city. The significant impact felt by the school on the education sector is the way in facing the changes that occur in the new government policies. For the reasons above, the creative skill program implemented by the Community Service Team in developing the students' interests and talents in art and culture is very beneficial. The vision of art and culture creativity skill program is "To instill an aesthetic sensitivity and cultural art intelligence through the learning of art and culture". The mission and target of art and culture creativity skill program is to enable students to accept the moral values or get an intelligent soft skill in cultural art, and appreciate traditional culture and local wisdom. Thus, the students will be able to:

1) Appreaciate the regional and national cultural arts;

2) Instill ethnical values in behaving;

3) Express the culltural arts verbally; and,

4) Show the cultural arts skill.

In this case, the creativity program of USU offered to its partner, the Improvement of Students' Creativity Skill of Art and Culture Program, is conducted out of the students' school hours. The condition of Sinar Serdang School is still limited in terms of facilities and educational staff. Yet, the team has designed a 20-hour study program for 5 weeks on every Friday and Saturday at 3 PM to 5 PM. The afternoon session will be filled with creativity development to increase the students' soft skills. So that, in the future, they will understand and apply aesthetic creativity in art and culture easily where it gives so much benefits. Next, the teacher makes a character learning plan that mathes these competitions and determines a suitable theme for this activity.

Choiri (2000:36) stated that the student learning success is influenced by three variables, those are educational facilities, learning methods, and motivation to learn. This happened because of the lack of school fees to do those thing. Another factor is the low income of the parents so the students cannot join a training or take additional lessons at school. In this learning activity, the team has prepared integrative learning methods and techniques along with the facilities needed in teaching and learning sessions such as syllabus, learning methods and techniques, tape recorders, and instructors. The program was integrated in 3 ways, those are 1) The learning of Malay art and culture, where students were thought to verbally convey the Serdang-Malay art and culture in brief, 2) Training or practice of simple local art and culture such as Malay dance or drama, and 3) Malay dance and drama performances. These three integrated programs have made them be able to apply the skills and develop their creativity.

\section{TRAINING METHOD BASED ON INTEGRATIVE LEARNING MODEL}

In implementing the activities to improve the students' soft skill such as local wisdom values and aprreciation of the culture, the team applied instructing, teaching, practicing, and cultural arts performing methods. In brief, they go through the processes such as:

1) The instruct method was used to provide a briefing introduction about the concepts of knowledge and procedures, and the learning of Malay cultural arts. The briefing on how to dance and perform drama for students in grade 7 and 8 of Islamic Junior High School by implementing the 20-hour Improvement of Teenager's Creativity Skill of Art and Culture program held for 2 weeks every Friday and Saturday at 3 PM to 5 PM.

2) The simulation method was used so that students could explain the concepts and procedures of Malay cultural art.

3) Methods of practice and practicum for applying the skills and mastery of dance and drama scripts directly to the students based on standard procedures (6 weeks).

4) The performance method is to apply the skills in order to grow and create students' confidence in developing their artistic potential for 1 week.

5) Evaluation methods are conducted for training students in order to obtain information about students' understanding of the given material.

6) Through the evaluation, the benefits of this activity will be known. In addition, this can be an evaluation to arrange the additional material as desired by participants in subsequent trainings. 


\section{DISCUSSION}

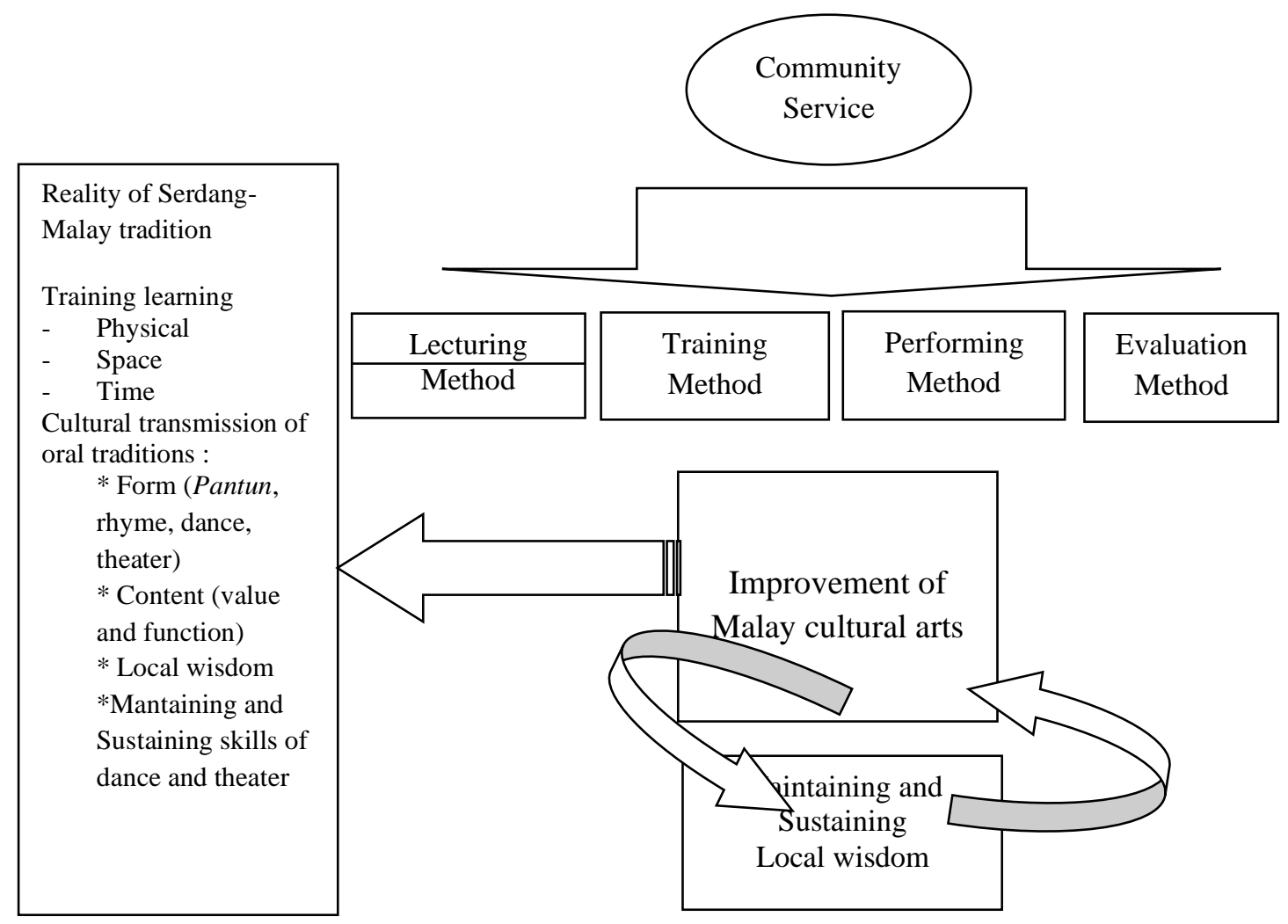

Figure 1. Community Service Mindset.

Through lecturing, practicing, and performing the creativity skills of dance, pantun reciting and theater in the school, the community service team has contributed socially and culturally. In the lecturing program on "Understanding and Mastering Verbal and Intellectual Information about Malay art and theater", the topic given by the teacher was "Respecting Traditional Culture", that were rhyming arts, dance, and Malay theater arts.

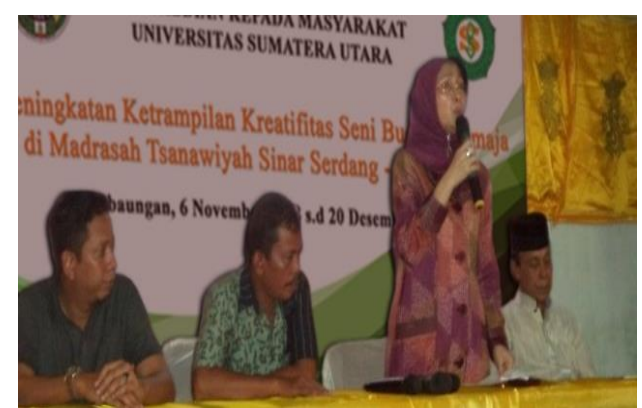

Picture 1. Opening Ceremony.

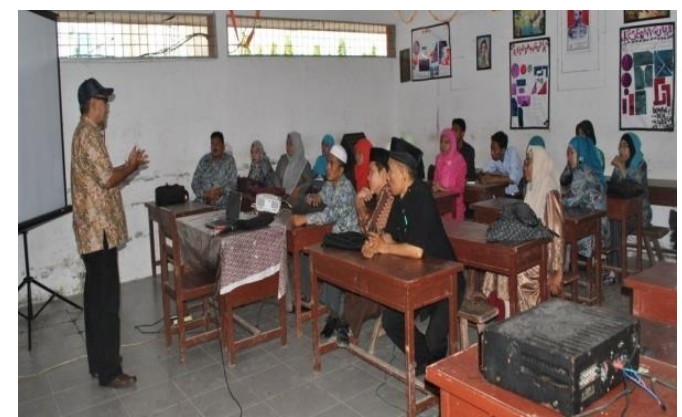

Picture 2. Briefing to the students' parents. 
a) The opening included greeting (5 minutes) and warming up (10 minutes) by giving a Pantun reciprocally to trigger crativity.

b) Bringing up a conceptual knowledge and philosophical background about the principle of local art and culture and the development of creativity (30 minutes).

1) Students were able to explain in simple and relevant language the terminology in Malay dance and theater.

2) Students were able to make Pantun due to mandate Malay advice in paying attention to the natural balance of the environment and society.

3) The learning techniques that the teacher used were explanatory techniques, questions and answers, and group works. After the explanation session, a question and answer session about the values contained in the teaching material follows.

a. Improving cultural art creativity skills is organized the learning experience to reach certain learning goals. Before the activity, the patterns and media had been designed to practice the skills and activities in order to put a pressure on:

1) Demonstrating dance moves by following the tempo of Senandung, Ma'inang;

2) Learning to play musical instruments, hitting gendang and gong; and,

3) Acting a character in the theater.

To achive the objectives, the teacher made an outdoor learning strategy. In the picture, it can be seen that students were listening to the instructions done by the teacher seriously. The teacher created an outdoor learning community in groups. In the group, the students collaborate in applying the values of art and culture that are closely related to the formation of one's character. By working in groups, the students learn the values of teamwork in the cultural processes to respect one another.

In this case, the condition that supports the effectiveness of the art learning process were carried out through the following techniques:

a. The technique of moving the fingers, flexing the fingers, and turning the fingers in and out;

b. The technique of stepping and estimating the distance between dancers;

c. The technique of swaying;

d. The technique of breath regulation and speaking in Malay dialect.

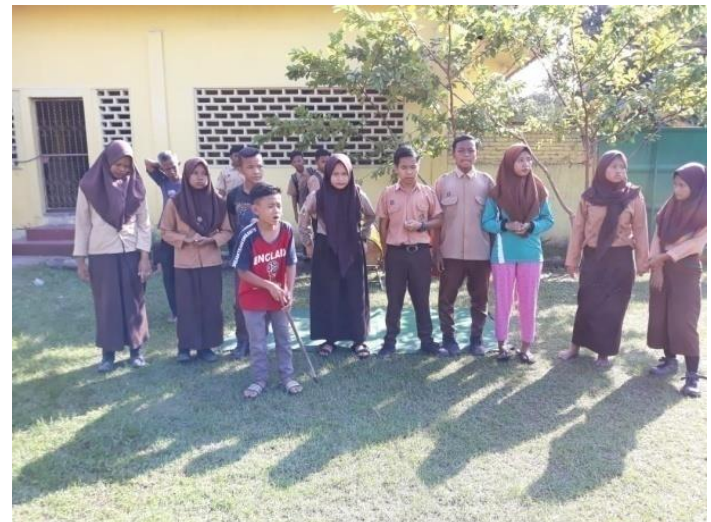

Picture 3. Students were listening to lecture.

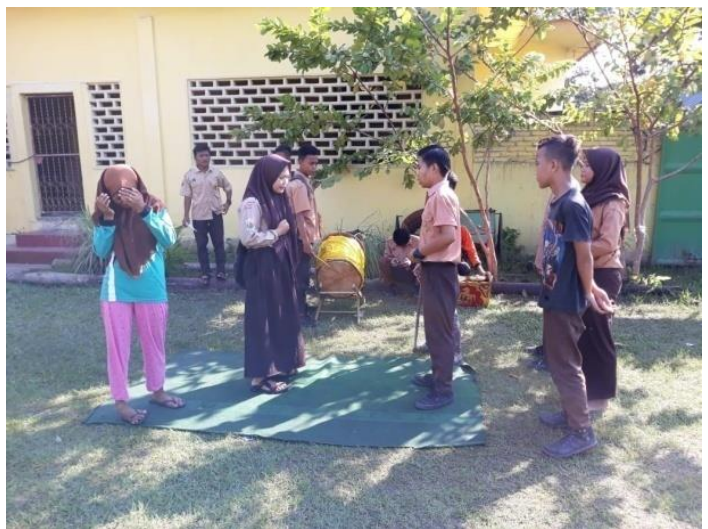

Picture 4. Students were doing a teamwork. 
The attitude of aesthetic and psychomotor experiences grow affective. They began to be sensitive to the fourth and sixth exercises. In addition, they were able to create expressions in dancing, making Pantun, and acting.
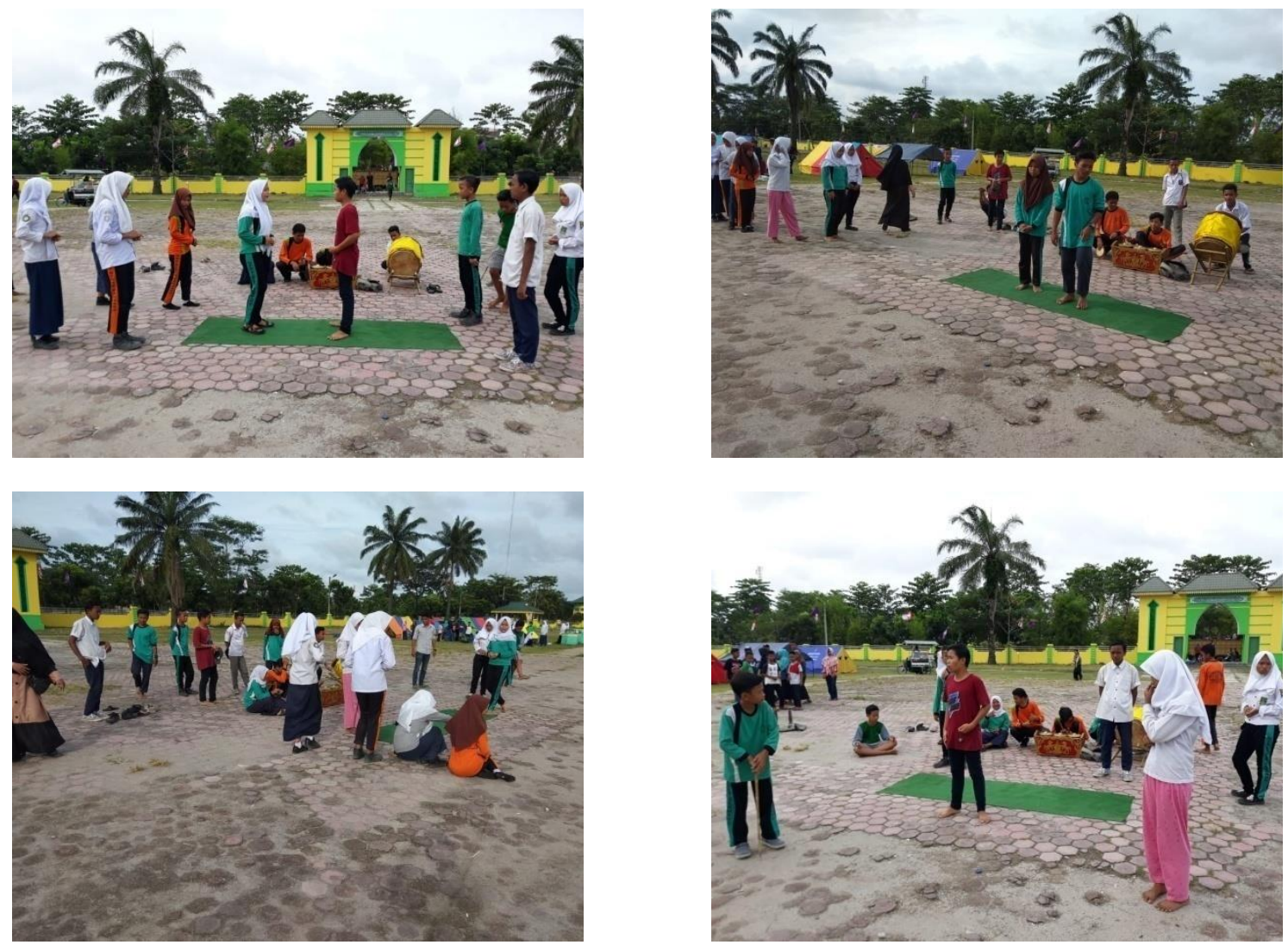

Picture 5 to 8. Practicing in the replica field of Istana Sultan Serdang - Serdang Bedagai.

Students were then asked to live the verbal expressions in Pantun which inherit the local wisdom of the Malay community to the young generation of Malay people. Some selected pantuns taken from the book "Pantun dan Pepatah Melayu" (Sinar, 2004) were learned continuously to get various rules and valuable philosophical background.

The Pantun teaches the students to be always discipline, speak politely, and be useful to others as set in the following Pantun:

Bila duduk, duduk bersifat

bila tegak, tegak beradat

bila bercakap, cakap berkhasiat

bila diam, diam bermakrifat.
When you sit, sit up straight

When you stand, stand up faith

When you speak, speak up fit

When you mute, mute but filled

Students were trained to live with the Pantun that contain curiosity of knowledge and try to deepen something they learn by seeing and hearing. Students were reminded of the importance of searching knowledge through the habit of reading various books that bring a goodness for them.

"Kalau duduk disuruh berguru,

kalau tegak suruh bertanya”.

"bila merantau mencari ilmu,

Bila berjalan mencari teladan

Bila berkayuh mencari contoh".
"When you sit mean to learn,
When you stand mean to question".
"When you travel mean to experience,
When you walk mean to pattern
When you row mean to lesson"

Students were trained to become a character who had a national spirit, attitude, and insight that place the interests of the nation and the state above anything. Students were trained to love the motherland and show loyalty, care, and high respect for the language, physical environment, social, cultural, economic, and political aspects of the nation.

Perahu payang layarnya merah, Belayar menuju arah utama, Keris dipegang bersentuhkan darah, Adat pahlawan membela Negara.
The red sailing cruise,

Sail to the main direction,

Hold a Keris bare to blood,

The way patriots defends the motherland 
Through Gurindam, students were trained to become a nation character who "cares for the environment and has attitudes and actions that always try to prevent any damages to the natural environment", and to develop efforts to repair natural damage that has already occurred.

Tanda orang memegang amanah, pantang merusak hutan dan tanah tanda ingat hari tua,

laut di jaga bumi dipelihara

tanda ingat Tuhan,

menjaga alam ia utamakan

tanda ingat adat lembaga,

laut dikungkung hutan dijaga

siapa sadar dirinya khalifah,

terhadap alam tak akan menyalah

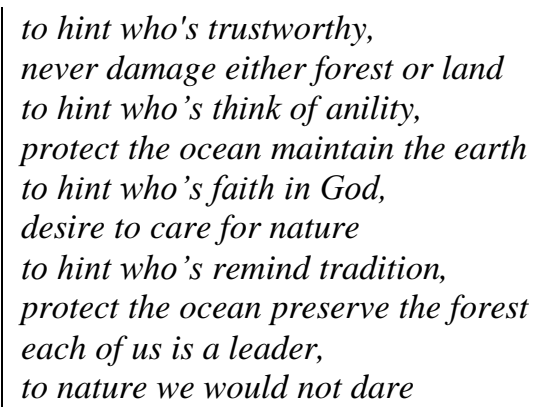

to hint who's trustworthy, never damage either forest or land to hint who's think of anility, protect the ocean maintain the earth to hint who's faith in God, desire to care for nature to hint who's remind tradition, protect the ocean preserve the forest each of us is a leader,

to nature we would not dare

During eight weeks of practicing, the students were accustomed to focus on the art learning process, while the teacher took role in guiding them to be able to use their new skills. The final goal should realize the ability to maintain and preserve the values that haved been obtained from the learning of "Respecting Traditional Culture and Local Wisdom". After completing the learning of art and culture for 8 weeks, they began to sharpen their soft skills with an aesthetic value thus to develop their character in principle.

As cultural assets of its authentic community, the local wisdom of Malay language especially in the global culture, is worth maintaining as it is one of the strength and characteristics of the Malay people in Indonesia.

\section{CONCLUSION}

By applying the learning model of art and culture which was integrated with character building, it definitely educates and guides students to understand the values contained in the art and culture. Yet, it provides knowledge, cultural arts practices, and behavior oriented to the ideal values of life.

Local wisdom is interpreted as a value education, character education, moral education, and personality education so that students can show good habits embraced by Malay people of Serdang through arts and culture. Improving Teenager's Creativity Skill of Art and Culture which was carried out in school can give meanings and benefits to the students' development of aesthetic experiences need in the form of expression/creative and appreciative activities. The aesthetic experience given in the learning of art and culture, in principle, succeeded in developing sensitivity to create religious values, moral values, and values of students' character. They were able to show their art performance in front of the District Head and Perbaungan Regency. The success in integrating the art and culture learning with character development can teach students to love and keep preserving the cultural values in the future.

Character building proposed by the government through the national education system policy must be rooted or based on local wisdom derived from the cultural traditions of certain society. This effort was carried out as a step to shape and strengthen the character and identity of the Indonesian nation in facing the great impact of the industrial revolution 4.0.

\section{REFERENCES}

Choiri, A. 2000. Sejumlah Fakta Penting yang Perlu Dipertimbangkan Untuk Mencapai Sukses Belajar. Warta Vol. 6. No.3 LPM. Surakarta: UMS Press.

Mulyasa, H.E. 2011. Manajemen Pendidikan Karakter. Jakarta: Bumi Aksara.

Muslich, M. 2011. Pendidikan Karakter: Menjawab Tantangan Krisis Multidimensional. Jakarta: Bumi Aksara.

Sinar, T.L. 2004. Pantun dan Pepatah Melayu, Medan: LPPSBM MABMI.

Sinar, T.S. 2011. Kearifan Lokal Berpantun Adat Perkawinan Melayu Batubara. Medan: USU Press

Wibowo, R. 2007. Ilmu Pengetahuan Sosial Sosiologi untuk SMP dan MTs Kelas IX. Jakarta: ESIS.

Kementerian Riset, Teknologi, Dan Pendidikan Tinggi Republik Indonesia. Tantangan di Era Revolusi Industri 4.0

Bagi Perguruan Tinggi Indonesia. 13 Nov 2018. https://www.ristekdikti.go.id/siaran-pers/pengembanganiptek-dan-pendidikan-tinggi-di-era-revolusi-industri-4-0/\#Z4OluqDM2ecB7Blx.99

https://www.youtube.com/watch?v=TRe78ZOMBcw : Proyeksi Pendidikan Abad 21

https://www.youtube.com/watch?v=xqbVLrw9RE4 : Kebangkitan Pemuda Kebangkitan Bangs 